\title{
ISOTOPIC COMPOSITION OF PYTERLITE IN VYBORG (VIIPURI), WIBORG BATHOLITH, RUSSIA
}

\author{
TAPANI RÄMÖ
}

\begin{abstract}
RÄMÖ, TAPANI 2001. Isotopic composition of pyterlite in Vyborg (Viipuri), Wiborg batholith, Russia. Bulletin of the Geological Society of Finland 73, Parts $1-2,111-115$.
\end{abstract}

Key words: granites, rapakivi, geochemistry, isotopes, neodymium, lead, Proterozoic, Vyborg, Russian Federation

Tapani Rämö: Department of Geology, P.O. Box 64, FIN-00014 University of Helsinki, Finland.E-mail: tapani.ramo@helsinki.fi

\section{INTRODUCTION}

Active worldwide research on rapakivi granites and related mafic and intermediate rocks has shown that this lithologic assemblage is an important tool in the study of the composition of deep continental crust and subcontinental mantle (see Haapala \& Rämö 1999 and references therein). In any one area, the radiogenic isotope composition of the rapakivi granites reflects the overall age of the unexposed lithosphere that they occupy (e.g., Rämö 1991, Neymark et al. 1994, Rämö et al. 1995, Andersson 1997, Dall'Agnol et al. 1999). This has recently been particularly well established for the $\sim 1.5 \mathrm{Ga}$ rapakivi granites of central Sweden that show a substantial Archean source component although no Archean crust has been found to be exposed in that area (Andersson 1997).

In the first part of the 1990's, the rapakivi batholiths of Russian Karelia were studied for $\mathrm{Nd}$ and $\mathrm{Pb}$ (as well as $\mathrm{Sr}$ ) isotopes that implied a mixed Archean-Paleoproterozoic source, in contrast to the clearly younger source characteristics of the rapakivi granites farther to the west in southern Finland (Rämö 1991, Neymark et al.
1994). The latter turned out to be quite homogeneous in terms of $\mathrm{Nd}$ and $\mathrm{Pb}$ isotopes with a clear Paleoproterozoic signature for all plutons extending from the Åland Islands in the west to the Finnish-Russian border in the east (Rämö 1991).

The Russian Karelian rapakivi batholiths (Salmi and Ulyalegi; Fig. 1a) are situated at the contact zone of the Archean and Paleoproterozoic crustal domains of the Fennoscandian Shield and their mixed (Archean-Proterozoic) isotopic signature is thus quite understandable. Recent studies on the Mesoproterozoic (Amantov et al. 1996, Rämö et al. 2001a) Valamo dolerite of the Jotnian Lake Ladoga basin have suggested that a Neoarchean subcontinental lithosphere (with $\varepsilon_{\mathrm{Nd}}$ [at $1.46 \mathrm{Ga}]$ of $\sim-9$ and initial ${ }^{87} \mathrm{Sr} /{ }^{86} \mathrm{Sr}$ of $\sim 0.705$ ) probably underlies the north-central part of Lake Ladoga (Upton et al. 1998, Rämö et al. 2001a; Fig. 1). This suggests that the Archean-Proterozoic boundary may continue at depth farther to the southwest than the present exposed boundary northwest of Lake Ladoga (Fig. 1a). In order to examine whether the easternmost part of the Wiborg batholith in Russian Karelia (southwest of Lake Ladoga) records a major Archean source 

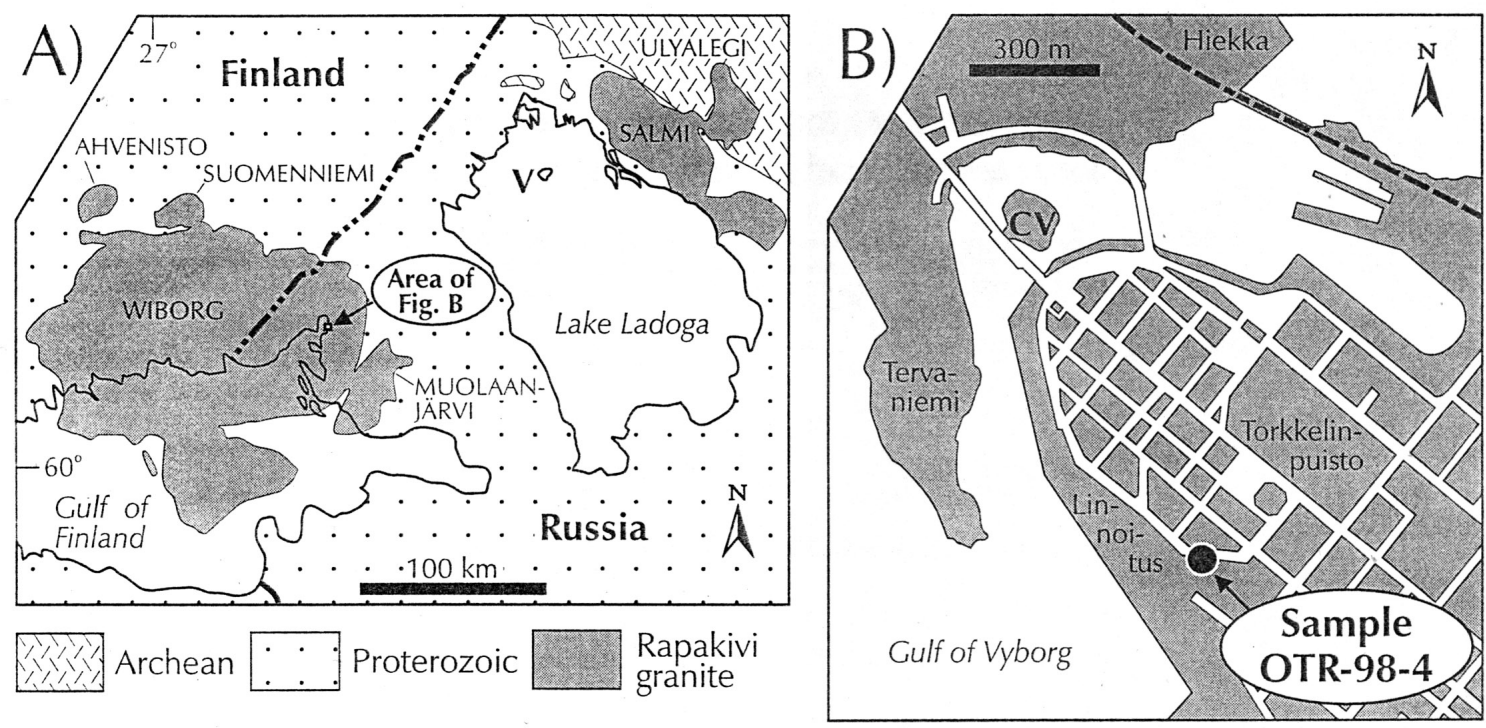

Fig. 1. (a) Geologic sketch map of southeastern Finland and adjacent Russian Karelia. Major rapakivi granite plutons of the area (Wiborg, Ahvenisto, Suomenniemi, Muolaanjärvi, Salmi, Ulyalegi) are indicated. V denotes the Island of Valaam in the northern part of Lake Ladoga where the Valamo dolerite is exposed. Note that the bedrock south of the Gulf of Finland, the Muolaanjärvi batholith, and Lake Ladoga is covered by Phanerozoic sedimentary rocks (not shown on the map). Modified from Fig. 1 in Laitakari et al. (1996). (b) Sketch map of downtown Vyborg (Viipuri) showing the location of sample OTR-98-4. CV marks the Castle of Vyborg; Finnish names of some city areas are also indicated.

component, a rapakivi granite sample from the town of Vyborg (Viipuri) was analyzed for $\mathrm{Nd}$ and $\mathrm{Pb}$ isotopes. This report presents the acquired data and their due implication.

\section{SAMPLE}

The analyzed sample, OTR-98-4, was collected in downtown Vyborg at a roadcut immediately to the west of the Bastion of Pantsarlahti, 900 m southsoutheast of the Castle of Vyborg (Fig. 1b). It is a coarse-grained hornblende-biotite granite with ovoidal alkali feldspar megacrysts (diameter 1-3 $\mathrm{cm}$; occasionally up to $5 \mathrm{~cm}$ ) some of which are mantled by oligoclase. Quartz is found as short prismatic (drop-like) early crystals (diameter up to $0.5 \mathrm{~cm}$ ) and as anhedral grains in the groundmass, plagioclase $\left(\sim \mathrm{An}_{20-30}\right)$ is present as turbid subhedral grains up to $0.7 \mathrm{~cm}$ in diameter. The main mafic silicates, biotite and hornblende, fill the interstic- es of feldspars and early quartz. Accessory minerals include apatite, zircon, fluorite, and oxide.

In terms of its petrography, sample OTR-98-4 is a pyterlite (cf. Wahl 1925, Vorma 1976) that, according to Simonen and Vorma (1969), covers $\sim 6 \%$ of the Finnish part of the Wiborg batholith. Overall, the bedrock of the downtown region of Vyborg is composed of pyterlite that is rather homogeneous, save for subtle variation in the size of the alkali feldspar megacrysts.

\section{RESULTS}

For the Vyborg pyterlite, $\mathrm{Nd}$ isotopic composition was determined from whole-rock fraction and $\mathrm{Pb}$ isotopes were measured for both whole-rock and alkali feldspar. The results of the isotopic analyses are shown in Table 1 and Fig. 2. Detailed descriptions of the analytical procedures can be found in Rämö et al. (2001b). 
Table 1. Nd and Pb isotopic composition of Vyborg pyterlite

Sample name

Sm (ppm)

$\mathrm{Nd}(\mathrm{ppm})$

${ }^{147} \mathrm{Sm} /{ }^{144} \mathrm{Nd}$

${ }^{143} \mathrm{Nd} /{ }^{144} \mathrm{Nd}^{\text {a }}$

$\varepsilon_{\mathrm{Nd} i}(1640 \mathrm{Ma})^{\mathrm{b}}$

$\mathrm{T}_{\mathrm{DM}}(\mathrm{Ga})^{\mathrm{c}}$

${ }^{206} \mathrm{~Pb} / 204 \mathrm{~Pb}^{\text {a }}$

${ }^{207} \mathrm{~Pb} / 204 \mathrm{~Pb}^{\text {a }}$

${ }^{208} \mathrm{~Pb} /{ }^{204} \mathrm{~Pb}^{\text {a }}$

${ }^{206} \mathrm{~Pb} /{ }^{204} \mathrm{~Pb}_{i}{ }^{\text {d }}$

${ }^{207} \mathrm{~Pb} /{ }^{204} \mathrm{~Pb}{ }_{i}{ }^{\mathrm{d}}$

${ }^{208} \mathrm{~Pb} /{ }^{204} \mathrm{~Pb}_{i}{ }^{\mathrm{d}}$

Note: Isotopic analyses at the Geological Survey of Finland (GTK). For analytical procedures, see Rämö et al. (2001b).

${ }^{\text {a }}$ Whole-rock values. ${ }^{143} \mathrm{Nd} /{ }^{144} \mathrm{Nd}$ normalized to ${ }^{146} \mathrm{Nd} /$ ${ }^{144} \mathrm{Nd}=0.7219$; reported error is $2 \sigma_{\mathrm{m}} . \mathrm{Pb}$ isotopic ratios reported relative to the NBS 981 standard.

${ }^{\mathrm{b}}$ Initial $\varepsilon_{\mathrm{Nd}}$ value, calculated using chondritic values of

${ }^{143} \mathrm{Nd} /{ }^{144} \mathrm{Nd}=0.51264$ and ${ }^{147} \mathrm{Sm} /{ }^{144} \mathrm{Nd}=0.1966$.

${ }^{c}$ Depleted mantle model age (DePaolo 1981).

${ }^{\mathrm{d}}$ Initial ratios, measured on alkali feldspar fraction.

\section{Nd isotopes}

The Vyborg pyterlite has quite high contents of Sm (18.44 ppm) and Nd (95.60 ppm) and it is strongly enriched in the light rare earth elements with ${ }^{147} \mathrm{Sm} /{ }^{144} \mathrm{Nd}$ of 0.1166 . This is typical of the Finnish, and for that matter, the Proterozoic rapakivi granites in general (e.g., Rämö \& Haapala 1995). The present-day ${ }^{143} \mathrm{Nd} /{ }^{144} \mathrm{Nd}$ of the sample is $0.511719 \pm 0.000009$, initial $\varepsilon_{\mathrm{Nd}}$ (at $1640 \mathrm{Ma}$ ) value -1.1 , and depleted mantle model age (calculated according to DePaolo 1981) $2071 \mathrm{Ma}$ (Table 1; Fig. 2a).

\section{Pb isotopes}

The whole-rock and alkali feldspar Pb isotopic ratios of the Vyborg pyterlite are relatively high and roughly conform to the Stacey and Kramers (1975) model for average crustal $\mathrm{Pb}$ (Fig. 2b). The wholerock - alkali feldspar pair defines a trend with an age of $\sim 1600 \mathrm{Ma}$ and a Th/U of $\sim 3.2$. The age, although quite imprecise, is compatible with the $\mathrm{U}-\mathrm{Pb}$ ages measured for the Finnish part of the Wiborg batholith; these cluster around $1640 \mathrm{Ma}$ (Vaasjoki 1977, Suominen 1991, Vaasjoki et al. 1991, Alviola et al. 1999). The Stacey and Kramers $\mu_{2}$ value and second-stage model age for the feldspar fraction are 9.87 and $1373 \mathrm{Ma}$, respectively.

\section{DISCUSSION AND CONCLUSION}

In Fig. 2a, the initial isotopic composition of the Vyborg pyterlite is shown and compared to the composition of the Finnish and Russian Karelian rapakivi granites in an $\varepsilon_{\mathrm{Nd}}$ vs. age diagram. Quite clearly, the Vyborg pyterlite conforms to the samples previously analyzed from the Finnish part of the Wiborg batholith and from the other Finnish rapakivi granites (Rämö 1991). These define a narrow evolution path with $\mathrm{Nd}$ model ages clustering around 2.1-2.0 Ga, whereas the Russian Karelian rapakivi granites are clearly less radiogenic, show more scatter, and have clearly older model ages.

The uranogenic $\mathrm{Pb}$ isotopic composition of the Vyborg pyterlite is compared to that of the alkali feldspar and whole-rock fractions analyzed from the Finnish and Russian Karelian rapakivi granites in Fig. 2b. Again, the pyterlite is compatible with the Finnish granites that fall along the growth curve of the Svecofennian crust, and it grossly deviates from the Russian Karelian feldspars and whole-rocks that show a much more unradiogenic composition and presumably reflect a major source component in a low-U/Pb Archean lower crust (Rämö 1991).

The $\mathrm{Nd}$ and $\mathrm{Pb}$ isotopic composition of the pyterlite from Vyborg shows that the easternmost (Russian) part of the Wiborg batholith also had a Paleoproterozoic protolith with no substantial contribution from an Archean source. As the rapakivi granites probably reflect, through anatexis, averaged isotopic composition of preexisting deep crust (e.g., Rämö 1991, Rämö \& Haapala 1995), this suggests that the concealed Archean domain 

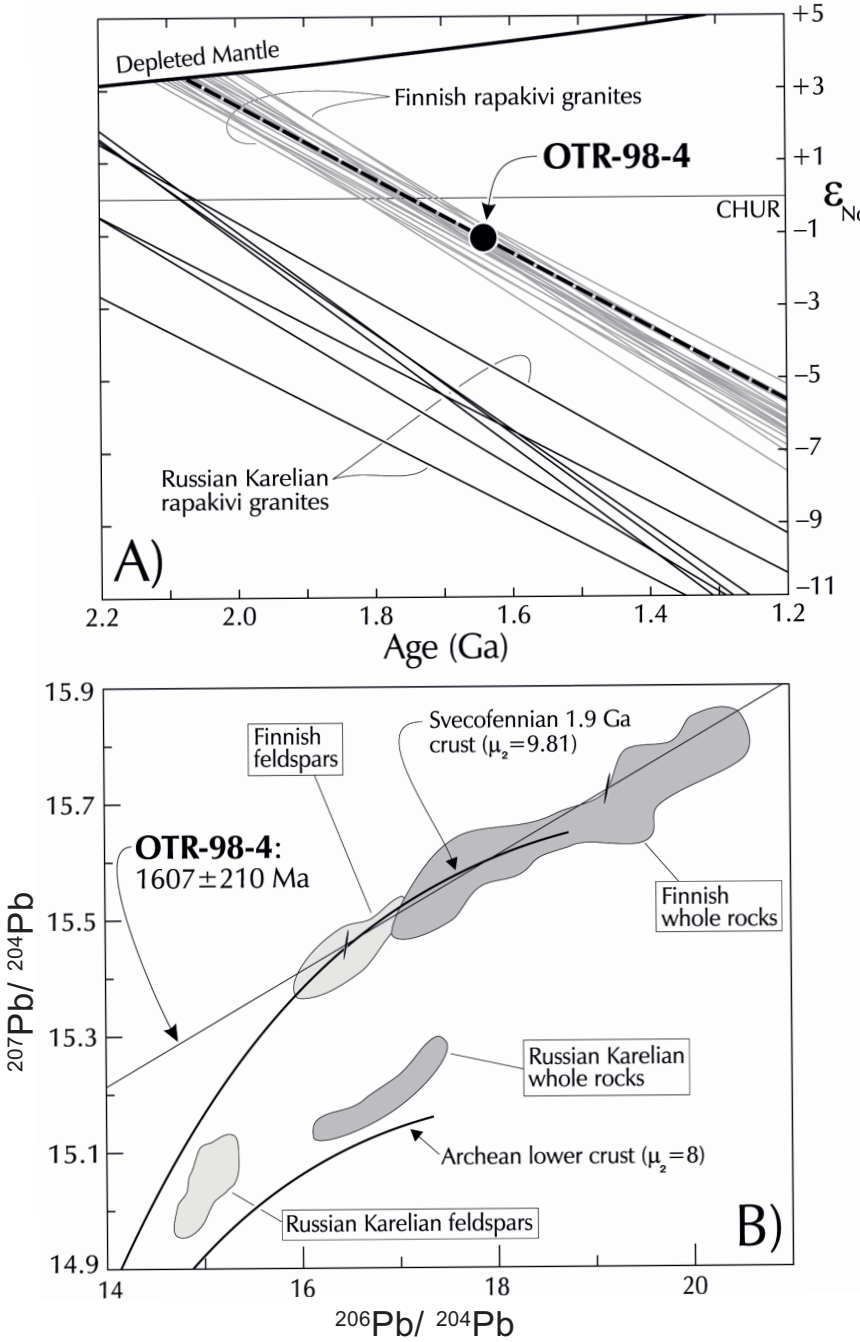

Fig. 2. (a) $\varepsilon_{N d} v s$. age diagram showing the initial Nd isotopic composition and evolution path (dashed line) of the Vyborg pyterlite (OTR-98-4). Compositions of the Finnish rapakivi granites (Rämö 1991) are indicated by gray evolution lines, those of the Russian Karelian rapakivi granites (Neymark et al. 1994, Rämö 1991) by black lines; highly fractionated topaz-bearing granites with anomalous $\mathrm{Sm}-\mathrm{Nd}$ ratios are excluded. Also shown is the evolution of depleted mantle (DePaolo 1981) and undifferentiated Earth (CHUR; DePaolo \& Wasserburg 1976). Symbol size of the Vyborg pyterlite indicates the maximum error in $\varepsilon_{N d}$. (b) ${ }^{206} \mathrm{~Pb} / 204 \mathrm{~Pb}$ vs. ${ }^{207} \mathrm{~Pb} /{ }^{204} \mathrm{~Pb}$ diagram showing the composition of the alkali feldspar and whole-rock fractions (black ellipses) analyzed from the Vyborg pyterlite. Data fields for the Finnish (Rämö 1991) and Russian Karelian (Neymark et al. 1994, Rämö 1991) rapakivi granites are also shown, as are Stacey and Kramers (1975) growth curves for the Svecofennian crust and for a hypothetical Archean lower crust (Rämö 1991). Symbol size of the Vyborg pyterlite data points is proportional to the $2 \sigma$ error in the variables. recorded by the dolerite in the Ladoga region does not extend southwestward across the Karelian Isthmus to the Wiborg batholith.

ACKNOWLEDGMENTS. Sampling in Vyborg was done in 1998 on a private trip to examine Finnish Continuation War (1941-1945) battle stations at Sormenkärki, Rajajoki. I would like to thank the staff of the Unit for Isotope Geology, Geological Survey of Finland for help while making the isotope analyses and Tuure Rämö, my father, for help in compiling the sketch map of Vyborg. Lars Rämö provided thin sections of the pyterlite and Martti Lehtinen was kind enough to apply a special cleaning procedure to remove lichen. Critical reviews of the manuscript by Veli Suominen and Matti Vaasjoki and editorial comments by Yrjö Kähkönen were helpful. Supported by the Academy of Finland (project 36002). Contribution to IGCP Projects 315 "Rapakivi Granites and Related Rocks" and 426 "Granite Systems and Proterozoic Lithospheric Processes".

\section{REFERENCES}

Alviola, R., Johanson, B.S., Rämö, O.T. \& Vaasjoki, M. 1999. The Proterozoic Ahvenisto rapakivi granite - massif-type anorthosite complex, southeastern Finland; Pe- 
trography and $\mathrm{U}-\mathrm{Pb}$ chronology. Precambrian Research 95, 89-107.

Amantov, A., Laitakari, I. \& Poroshin, Ye. 1996. Jotnian and Postjotnian: sandstones and diabases in the surroundings of the Gulf of Finland. In: Koistinen, T. (ed.) Explanation to the map of Precambrian basement of the Gulf of Finland and surrounding area 1: 1 million. Geological Survey of Finland, Special Paper 21, 99-113.

Andersson, U.B., 1997. Petrogenesis of some Proterozoic granitoid suites and associated basic rocks in Sweden (geochemistry and isotope geology). Sveriges geologiska undersökning, Rapporter och meddelanden nr 91.216 p.

Dall'Agnol, R., Rämö, O.T., de Magalhães, M.S. \& Macambira, M.J.B. 1999. Petrology of the anorogenic, oxidised Jamon and Musa granites, Amazonian Craton: Implications for the genesis of Proterozoic A-type granites. Lithos 46, 431-462.

DePaolo, D.J. 1981. Neodymium isotopes in the Colorado Front Range and crust-mantle evolution in the Proterozoic. Nature 291, 193-196.

DePaolo, D.J. \& Wasserburg, G.J. 1976. Nd isotopic variations and petrogenetic models. Geophysical Research Letters 3, 249-252.

Haapala, I. \& Rämö, O.T. 1999. Rapakivi granites and related rocks: an introduction. Precambrian Research 95, $1-7$.

Laitakari, I., Rämö, O.T., Suominen, V., Niin, M., Stepanov, K. \& Amantov, A. 1996. Subjotnian: Rapakivi granites and related rocks in the surroundings of the Gulf of Finland. In: Koistinen, T. (ed.) Explanation to the map of Precambrian basement of the Gulf of Finland and surrounding area $1: 1$ million. Geological Survey of Finland, Special Paper 21, 59-97.

Neymark, L.A., Amelin, Yu.V. \& Larin, A.M. 1994. Pb$\mathrm{Nd}-\mathrm{Sr}$ isotopic constraints on the origin of the 1.54-1.56 Ga Salmi rapakivi granite-anorthosite batholith (Karelia, Russia). Mineralogy and Petrology 50, 173-194.

Rämö, O.T. 1991. Petrogenesis of the Proterozoic rapakivi granites and related basic rocks of southeastern Fennoscandia: $\mathrm{Nd}$ and $\mathrm{Pb}$ isotopic and general geochemical constraints. Geological Survey of Finland, Bulletin 355. $161 \mathrm{p}$.

Rämö, O.T. \& Haapala, I. 1995. One hundred years of rapakivi granite. Mineralogy and Petrology 52, 129-185.

Rämö, O.T. \& Haapala, I., Vaasjoki, M., Yu, J. \& Fu, H.
1995. The 1700 Ma Shachang complex, northeast China: Proterozoic rapakivi granite not associated with Paleoproterozoic orogenic crust. Geology 23, 815-818.

Rämö, O.T., Mänttäri, I., Vaasjoki, M., Upton, B.G.J. \& Sviridenko, L. 2001a. Age and significance of Mesoproterozoic CFB magmatism, Lake Ladoga region, NW Russia. Geological Society of America, Abstracts with Programs 33(6), A-139.

Rämö, O.T., Vaasjoki, M., Mänttäri, I., Elliott, B.A. \& Nironen, M. 2001b. Petrogenesis of the post-kinematic magmatism of the Central Finland Granitoid Complex I; Radiogenic isotope constraints and implications for crustal evolution. Journal of Petrology 42, 1971-1993.

Simonen, A. \& Vorma, A. 1969. Amphibole and biotite from rapakivi. Bulletin de la Commission géologique de Finlande 238. 28 p.

Stacey, J.S. \& Kramers, J.D. 1975. Approximation of terrestrial lead isotope evolution by a two-stage model. Earth and Planetary Science Letters 26, 207-221.

Suominen, V. 1991. The chronostratigraphy of SW Finland with special reference to the Postjotnian and Subjotnian diabases. Geological Survey of Finland, Bulletin 356. $100 \mathrm{p}$.

Upton, B.G.J., Rämö, O.T., Vaasjoki, M., Sviridenko, L.P. \& Svetov, A. 1998. Constraints on petrogenesis of Mesoproterozoic CFBs from the SE Fennoscandian Shield: Trace element and $\mathrm{Nd}$ isotopic evidence. Abstracts of ICOG-9, 1998 Beijing, Chinese Science Bulletin 43, 134.

Vaasjoki, M. 1977. Rapakivi granites and other postorogenic rocks in Finland; Their age and the lead isotopic composition of certain associated galena mineralizations. Geological Survey of Finland, Bulletin 294. 64 p.

Vaasjoki, M., Rämö, O.T. \& Sakko, M. 1991. New U-Pb ages from the Wiborg rapakivi area: Constraints on the temporal evolution of the rapakivi granite-anorthositediabase dyke association of southeastern Finland. Precambrian Research 51, 227-243.

Vorma, A. 1976. On the petrochemistry of rapakivi granites with special reference to the Laitila massif, southwestern Finland. Geological Survey of Finland, Bulletin 285.98 p.

Wahl, W. 1925. Die Gesteine des wiborger Rapakiwigebietes. Fennia 45 (20). 127 p. 